\title{
Mean Platelet Dry Mass
}

National Cancer Institute

\section{Source}

National Cancer Institute. Mean Platelet Dry Mass. NCI Thesaurus. Code C114214.

The determination of the amount of mean platelet dry mass present in a sample. 